К. М.Ніколаєиь,

д. іст.н., професор кафедри економічної теорї̈ та конкурентної політики

Київсъкий начіональний торговельно-економічний університет

ORCID ID: 0000-0002-0471-2895

O. Ю. Ніколаєив,

здобувач освітнъого ступенл "бакалавр"

спечіальність"Міжнародні економічні відносини",

Київський начіональний торговельно-економічний університет

ORCID ID: 0000-0003-4832-0014

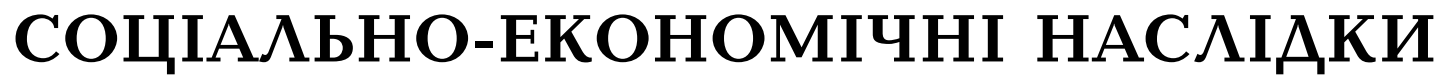 ЗОВНІШНЬОї ТРУАОВОї МІГРАЦІї
}

\author{
K. Nikolaiets, \\ Doctor of Sciences in history, Professor of the Department of Economics and Competition Policy Kyiv National University \\ of Trade and Economics \\ O. Nikolaiets \\ Bachelor degree in Field of Science of "International economic relation" \\ of Kyiv National University of Trade and Economics
}

\section{SOCIAL-ECONIOMIC RESULTS OF INTERNAL LABOR MIGRATION}

Визначено характер залежності розвитку економіки України від темпів та напрямів зовнішньої трудової міграції на початку ХХІ СТ. Висвітлено вплив змін на ринку праці України на темпи зовнішньої трудової міграції. На основі дослідження статистичних матеріалів, результатів соціологічних опитувань охарактеризовано зміни ставлення українських заробітчан залежно від їхнього віку до повернення на постійну роботу в Україні. Визначено вплив заходів державного регулювання розвитку малого, середнього та великого бізнесу на темпи зовнішньої трудової міграції. Охарактеризовано масштаби фінансових надходжень від зовнішніх трудових мігрантів до України, а також характер використання цих коштів. Визначено специфіку державної міграційної політики в умовах зростання масштабів надходження коштів від зовнішніх трудових мігрантів. Визначено вплив такого зростання на розвиток певних галузей економіки.

The nature of the dependence of the development of the Ukrainian economy on the rates of foreign labor migration at the beginning of the 21st century has been determined. The influence of changes in the labor market of Ukraine on the rate of external labor migration is highlighted. Based on the study of statistical materials, the results of sociological surveys, the changes in the attitude of Ukrainian wage earners, depending on their age, before returning to permanent employment in Ukraine are characterized. The influence of measures of state regulation of development of small, medium and large business on the rate of external labor migration is determined. The scope of financial income from external labor migrants to Ukraine is described, as well as the nature of the use of these funds. The specifics of the state migration policy in the conditions of increasing the amount of funds from external labor migrants are determined. It has been determined that the situational use of the funds of external labor migrants to improve the balance of payments, stabilize the Ukrainian currency, reduce social tensions in society is already facing problems that in the near future may create a whole complex of threats to national security.

The growing scale of external labor migration has led to a reduction in Ukraine's innovation potential due to the loss of the most skilled workers and, consequently, the inability to implement innovative projects. This has created additional barriers to increasing foreign investment through the dissemination of information about the 
difficulty of self-realization by skilled workers in Ukraine. It is determined that a significant number of Ukrainian enterprises are experiencing a shortage of skilled workers. As a result of the search of part-time workers abroad in Ukraine, a shortage of workers of working specialties has been created, which causes an increase in their wages. And such growth is already causing dissatisfaction among higher-skilled workers, whose level of remuneration, in their opinion, does not correspond to qualification. Due to the increase in the scope of external labor migration, the wage bill of the so-called blue collar workers has approached or exceeded the white collar wage bill. Therefore, to the conviction of many young workers in Ukraine, their self-realization cannot be ensured.

Ключові слова: зовнішні трудові міграчї, сочіальна політика, міграчійна політика, міграчї̈ населення, зайнятість населення, трудові маятникові міграчіі.

Key words: internal labor migration, social policy, migration policy, population migration, population employment, labor pendulum migration.

\section{ПОСТАНОВКА ПРОБЛЕМИ}

Поширення міжнародної трудової міграції як один із наслідків і проявів глобалізації має місце у більшості країн світу. Масштаби міграційних явищ знаходяться в прямій залежності від ендогенних (стагнація економіки, високий рівень безробіття, недосконалість системи соціального захисту тощо) та екзогенних (світового економічного розвитку, привабливі умови на ринку праці іноземних країн тощо) факторів. На початку XXI ст. було помічене зростання темпів зовнішньої трудової міграції з України. Ао 2014 р. більшість українських трудових мігрантів виїжджали до Російської Федерації. Aле після початку російсько-української війни на Аонбасі та в умовах запровадження безвізового режиму із країнами ЄС мало місце суттєве скорочення кількості трудових мігрантів до РФ та різке зростання масштабів трудової міграції до країн Європейського Союзу. Зміна вектору зовнішньої трудової міграції поступово почала справляти помітний вплив на розвиток української економіки. Значна частина трудових мігрантів, які свого часу виїжджали до Росії, не планували залишитися там на постійне проживання. Своє завдання вони бачили у тому, щоб заробити певні кошти для їх використання в Україні (переважно для купівлі житла, побутової техніки, автомобілів тощо). Відсутність мовного бар'єру, наявність родичів у РФ для багатьох трудових мігрантів ставали вагомими факторами вибору напряму міграції. Однак після подій 2014 р. Російська Федерація стала сприйматися багатьма українцями як країна-агресор, а праця на її теренах — як допомога тим, хто воює проти України. Крім того, негативний вплив справило й створення російською стороною додаткових перепон для українських трудових мігрантів у вигляді обмеження терміну перебування або складання іспиту на знання російської мови. Почастішали й випадки, коли із заробітчанами з України не розплатилися російські роботодавці, а також випадки відмови у дозволі на перетинання кордону із РФ для українських громадян.

Разом з тим після запровадження безвізового режиму з ЕС все більше українців стали виїжджати туди у пошуках роботи. Ситуація у європейських країнах для українських трудових мігрантів мала ряд відмінностей порівняно із тією, що склалася у Російській Федерації. Аеякі держави (наприклад, Польща, Чехія, Німеччина) запровадили заходи, що стимулювали приплив зовнішніх трудових мігрантів. Найбільш лояльним до українських мігрантів виявилося керівництво Польщі, яка за їх допомогою останнім часом змогла суттєво покращити свої макроекономічні показники. 3 часом ситуація на краще змінилася й у Чехії та Німеччині, які були зацікавлені у зростанні масштабів використання порівняно дешевої та освіченої української робочої сили. Іншим важливим чинником стало поступове заохо- чення молоді 3 України до навчання за кордоном. Перспектива набуття професійних навиків, що користуються попитом на ринку робочої сили у ЄС, стала приваблювати все більше молодих українців. Крім того, порівняно вищим, аніж у РФ, виявився рівень соціальної захищеності трудових мігрантів. Попри певні проблеми із легальним працевлаштуванням для окремих категорій працівників, частина українських трудових мігрантів, чиї професійні знання виявилися конкурентними, змогли легалізуватися у ЕС i сприяли подальшому працевлаштуванню своїх родичів чи знайомих.

Інтеграція України у європейський та світовий ринок робочої сили та освітніх послуг поступово позначилася на розвитку економіки держави. Характер впливу зовнішніх трудових мігрантів на економіку України постав вагомим чинником змін економічного розвитку держави.

\section{АНАЛІЗ ОСТАННІХ ДОСЛІДЖЕНЬ} І ПУБЛІКАЦІЙ

Окремі аспекти обраної теми дослідження представлені у працях А. Гайдуцького[6], О. Кваші [11, с. 535540], О. Корнієнко [13, с. 28-43], О. Малиновської [15; 16 , с. $104-114 ; 17 ; 18]$, Е. $\Lambda$ ібанової [14, с. 11-26], І. Прибиткової [26, с. 316-327], Т. Петрушиної, І. Соколовського [23, с. 139-147]. Значний інтерес викликають висновки авторів національної доповіді "Українське суспільство: міграційний вимір" [30] та працівників Інституту регіональних досліджень імені М.І.Аолішнього [20; 29]. Серед зарубіжних вчених у контексті нашого дослідження можна назвати праці I. Ажозвіка та М. Печовської [32]. У дослідженнях науковців здійснено аналіз закономірностей та виділено особливості українських реалій міграції крізь призму глобальних викликів та сучасних ризиків трансформації ринку праці. О. Малиновська проаналізувала чинники та наслідки міжнародної міграції, їі значення для розвитку та безпеки, а також виокремила перспективні напрями міграційної політики України. Е. Цібанова висвітлила можливі наслідки масштабної зовнішньої трудової міграції українців у контексті визначення перспектив реалізації інноваційних технологій в Україні. Специфіку напрямків трудової міграції визначила I. Прибиткова, яка показала процес формування ринків праці у межах України залежно від рівня розвитку окремих регіонів та населених пунктів.

\section{МЕТА ДОСЛІДЖЕНЬ}

Метою дослідження $€$ визначення основних наслідків зростання масштабів зовнішньої трудової міграції з України у контексті їі впливу на економіку держави. 


\section{ВИКЛАД ОСНОВНОГО МАТЕРІАЛУ ДОСЛІДЖЕННЯ}

Формування та розвиток ринкової економіки в Україні обумовили ряд чинників, які визначали причини та характер зовнішньої трудової міграції.

На початку XXI ст. в Україні загострилася конкурентна боротьба у деяких сферах виробництва між Арібним та середнім бізнесом, з одного боку, і великими підприємцями - 3 іншого. Критичні зауваження науковців часто лунали на адресу українських урядів, що діяли в інтересах зацікавлених у перерозподілі державної власності на свою користь великих фінансово-промислових груп.

Специфіка антимонопольного законодавства і практика його застосування додатково сприяла посиленню великих фінансово-промислових груп (ФПГ). Важливим чинником, який сприяв успіху ФПГ, стала можливість приватизації об'єктів, що забезпечували постачання електроенергії. Приватизація ряду обленерго дозволила суттєво впливати на визначення цін на електроенергію. Крім того, посилення окремих великих ФПГ було пов'язане із запровадженням 31 травня 2016 р. формули Роттердам+ - методики формування ціни на паливну складову (вугілля) під час виробництва електроенергії тепловими електростанціями України. Ціна вугілля розраховувалася на основі індексів у портах Амстердама, Роттердама та Антверпена із додаванням вартості транспортування вугілля з цих портів до України. Водночас більшість вугілля, яке споживалося вітчизняними TEC, видобувалося в Україні. Ця формула перестала діяти лише 31 липня 2019 р. 3 початком дії закону про ринок електроенергії, що був ухвалений Верховною Радою України у квітні 2017 р. запровадження формули Роттердам + зайвий раз підтвердило рентний характер олігархічного режиму в Україні.

Ціноутворення на ринку енергоносіїв, а також підвищення розміру мінімальної заробітної плати поставили дрібних підприємців у дуже скрутне становище. Суттєві проблеми це створило й для представників середнього бізнесу. Багато підприємців не мали можливості виплачувати працівникам зарплату згідно із новими правилами. Це призвело, з одного боку, до "тінізації" економіки, коли роботодавці виплачували працівникам офіційно лише мінімальну зарплату, а інші гроші передавали їм не офіційно, а з іншого - до різкого скорочення кількості малих підприємств, до припинення діяльності ФОПів. За підтримки урядами України великого бізнесу малі та середні підприємці не витримували конкуренції, були змушені згортати виробництво, підприємницьку діяльність. Це спричинило збільшення тих, хто змушений був шукати роботу або за їі відсутності, або через низький рівень оплати праці.

Штучне сприяння здешевленню робочої сили за рахунок орієнтації більшості підприємців виключно на розміри визначеної у Законі мінімальної заробітної плати сприяє прискоренню збагачення монополістів, що працюють на зовнішній ринок, але знижує купівельну спроможність населення, а відповідно ускладнює становище вітчизняних виробників, орієнтованих на внутрішній ринок. Низький розмір середньостатистичної зарплати в Україні постав на заваді не лише розвитку внутрішнього ринку, а й формуванню стійкої мотивації до трудової діяльності певного виду та тісного зв'язку між працівником і фірмою-роботодавцем, що сприяє зростанню рівня плинності кадрів. В Україні продовжує спостерігатись дивне для Європи явище бідність працюючих [3].

O.А. Рахманов у 2014 р. справедливо відзначив, що у перші посткомуністичні роки приватний капітал, що тільки формувався, вдало домагався результатів за рахунок шахтарського протестного руху, який "червоні директори" використовували з метою державної підтримки збиткових шахт. Однак з середини $90-\mathrm{x}$ років у владу почали рухатися нові багатії, яких умовно на- зивали "трейдерами" та "фінансистами", які навчилися накопичувати власний капітал за рахунок так званих вмираючих активів. Саме фінансисти були першими організаторами економічних процесів, відкривачами зовнішнього ринку [27, с. 378-396]. Значна частина 3 них використовувала порівняно низьку оплату праці як засіб конкурентного протистояння із виробниками на світовому ринку. Здешевлення робочої сили в Україні стало однією із особливостей переходу до ринкової економіки.

Проте порівняно низький рівень оплати праці в Україні став причиною обмеження доступу до матеріальних благ значної частини українського соціуму. На початку XXI ст. поширювалася практика, коли роботодавці, вважаючи, що вони забезпечують працівникам засоби до існування, своїми невиваженими діями (зверхнім ставленням, нехтуванням порадами професіоналів тощо) сприяли посиленню ротації кадрів, частковій їх перекваліфікації та виїзду кваліфікованих працівників за межі України [10, с. $21-26 ; 21$, с. 3-11; 31, с. 30-33].

Крім того, невиважена соціальна політика не лише дискредитувала в очах пересічних громадян державні органи, а й призводила до загострення соціальної напруженості у суспільстві та поширення "тіньової" економіки, як одного із засобів підвищення реальних доходів за рахунок ухилення від сплати податків [4, с. 4$8 ; 12 ; 19 ; 28]$. Аискредитація державних органів у очах громадян України посилювалася й унаслідок корумпованості деяких чиновників. В умовах війни українське суспільство сприймало це досить болісно.

Системне і тривале посилення тиску на дрібний та середній бізнес в Україні на початку XXI ст., яке ще більше зросло в умовах протистояння із Російською Федерацією, різко збільшило кількість тих, хто був готовий до зміни місця проживання задля пошуку роботи як такої, а також з метою підвищення розмірів заробітку. Частина громадян втратила надію на самореалізацію в Україні в умовах засилля олігархів та тотальної корупції. І усвідомлення цього багатьма громадянами відбулося ще до початку російсько-українськоӥ війни. Агресивні дії РФ, з одного боку, та запровадження безвізового режиму 3 країнами ЄС - 3 іншого, сприяли різкому зростанню кількості трудових мігрантів з України, які виїжджали у пошуках роботи до європейських країн (рис. 1).

Якщо у 2012 р. на тимчасові заробітки за кордон протягом найближчого року планували поїхати 5,3 \% українських громадян, то у 2018 р. такі наміри висловили 14,6 \% опитаних. Серед останніх переважали чоловіки $(17,9 \%$ порівняно із $11,8 \%$ жінок) і молодь $(22,5 \%$ серед респондентів віком до 30 років планували поїхати за кордон протягом найближчого року). Ситуація, коли кожен п'ятий молодий українець має намір працевлаштуватися за кордоном, свідчить про кризу внутрішнього ринку праці, а також загрожує утриманню зростаючої кількості пенсіонерів [1].

За даними МОМ у 2014 р. заощадження українських трудових мігрантів, які працювали за кордоном, становили близько 4 млрд дол. Переважну більшість цих коштів $(60 \%)$ українські заробітчани планували використати після повернення на Батьківщину [5]. I це не дивно 3 огляду на те, що серед мігрантів переважали чоловіки віком близько 40 років, які розглядали свою роботу за кордоном як тимчасову і спрямовану на покращення матеріального становища власних сімей. Ситуація змінилася починаючи з 2017 р., коли зовнішня трудова міграція стала все більше приваблювати українську молодь. Однією із причин цього стало різке зниження рівня життя населення. Так, середня заробітна плата у 2013 р. становила близько 408 дол., у 2014 р. 204 дол., у 2015 р. - 182 дол., а у 2016 р. - лише 165 дол. За номінального зростання середньої заробітної плати iii еквівалент у американських доларах різко зменшився. Якщо у 2013 р. споживчі ціни зросли лише на $0,5 \%$, 


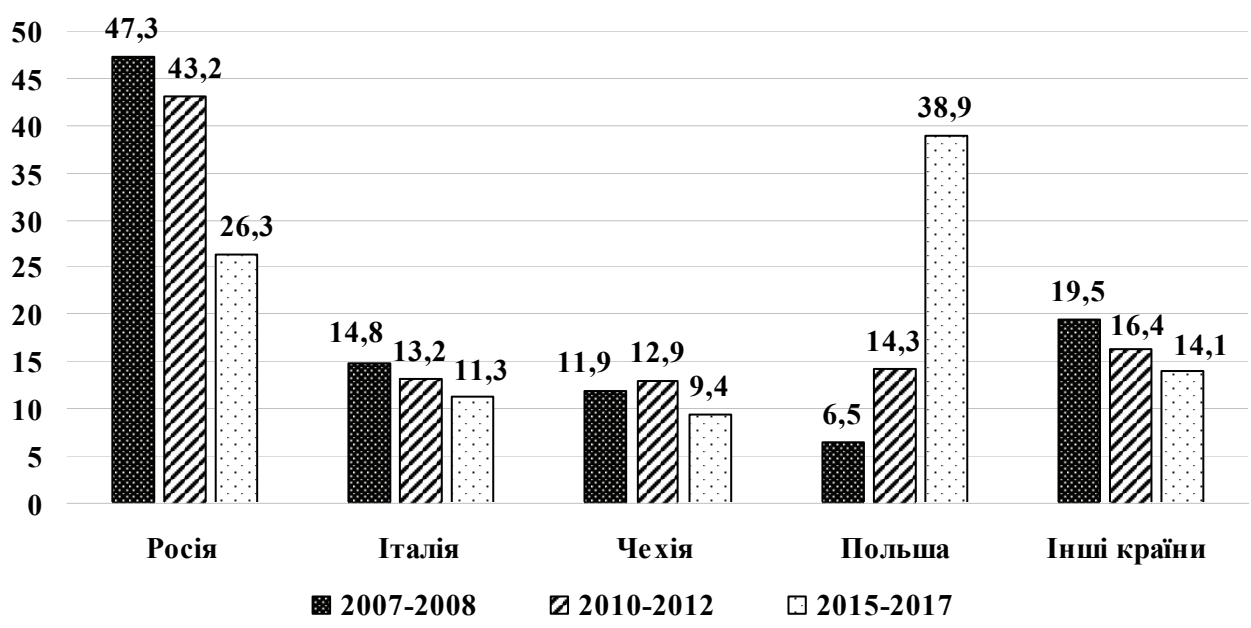

Рис. 1. Структура потоків зовнішніх міграцій, за країнами призначення, \%

то у 2014 році - майже на $25 \%$, у 2015 році - на $43 \%$, що негативно позначилося на купівельній спроможності громадян. Водночас у 2014 р. знайти роботу у своєму населеному пункті за кваліфікацією і достатнім рівнем заробітку було важно для 85,1 \% громадян, а будь-яку роботу - для 60,0 \%. У 2018 р. ці показники становили, відповідно, 73,8 \% і 45,1 \%. Тобто троє з чотирьох українців не могли знайти у своєму населеному пункті роботу за кваліфікацією та 3 достатнім рівнем оплати $[23$, с. 140$]$. І це без урахування показників по тимчасово непідконтрольних територіях, населення яких було орієнтоване на працю саме на території свого населеного пункту (промислові підприємства відігравали важливу роль у формуванні поселенської структури населення).

Ситуацію ускладнило й різке зростання тарифів на комунальні послуги у 2016 р., що серед іншого ускладнило оренду житла в Україні для внутрішніх трудових мігрантів. Крім того, у цей час багато громадян усвідомили затяжний характер протистояння із Російською Федерацією. Якщо у 2014 р. багато мешканців України вважали, що війна от-от закінчиться, то продовження бойових дій у 2015 р., примусило їх переглянути свою позицію. У таких умовах все більша кількість молодих людей полишала надії на самореалізацію в межах $\mathrm{У}_{\mathrm{K}-}$ раїни. Молодь приваблювала також можливість побачити світ. Водночас значна кількість українських мігрантів виявилася досить невибагливою у плані вибору роботи в країнах ЄС, погоджуючись на порівняно некваліфіковану працю, оплата за яку була все одно вищою, аніж в Україні. Крім того, якщо практика працевлаштування у РФ суттєво не відрізнялася від загальноприйнятих практик в Україні, то у країнах ЄС у цьому плані існували суттєві відмінності. Багатьох мігрантів, окрім порівняно високих заробітків, приваблювало верховенство закону і вищий рівень захисту інтересів професійних працівників (які були офіційно працевлаштовані). Значну роль відігравало також переконання у стабільності економічного розвитку, перспективності роботи чи організації бізнесу. Проте розвиток малого бізнесу, наприклад, у Польщі не був пов'язаний із значними бюрократичними перепонами чи загрозою рейдерства, як це мало місце в Україні. Все це сприяло поширенню переконання у перспективності працевлаштування у країнах ЄС. Одним із наслідків цього стали зміни вікової структури зовнішніх трудових мігрантів за рахунок зростання питомої ваги молодих людей.

Ао отримання безвізу, у період з 2015 до початку 2017 pр. на заробітки за кордон хоча б одноразово виїжджали 1,3 млн українців. Загальні масштаби трудової міграції можна було оцінити у $2-3$ млн осіб. I більшість
3 них становили короткострокові мігранти. Але після отримання безвізу кількість мігрантів зросла утричі. Практично кожен п'ятий громадянин України $(17,9 \%)$ у 2018 р. виїжджав за кордон на заробітки, а кожен десятий - двічі або навіть більше трьох разів - 10,3% і 12,8 \% відповідно. Зарубіжні заробітки стали основною дохідною статтею бюджетів багатьох домогосподарств. За оцінками майже половини опитаних $(46,2 \%)$, у сім'ях їх знайомих, члени яких працюють за кордоном, ці заробітки становлять понад $50 \%$ бюджету сім'ї, а на думку третини респондентів $(35,8 \%)$, - від $20 \%$ до $50 \%$ [2, с. 170]. Найбажанішими країнами для зовнішньої трудової міграції стали Польща, Німеччина та Італія (рис. 2).

Зростання надходжень від трудових мігрантів протягом відбувалося досить високими темпами. Якщо у 2017 р. надходження від зовнішніх трудових мігрантів до України за даними НБУ становили 9,3 млрд дол., то у 2018 р. - 11,6 млрд дол. Водночас у 2019 р. очікувалося зростання таких надходжень до 12,2 млрд дол. Проте у загальній структурі прямих іноземних інвестицій в УКраїну у 2016 р. близько 4,4 млрд дол. були переказами трудових мігрантів з Російської Федерації. У НБУ відзначали зростання обсягів коштів, які були ввезені в Україну нелегально [22]. За даними НБУ, у 2016 році обсяги приватних грошових переказів становили 5,5 млрд дол. або 5,8\% ВВП, з яких 20\% надійшли неформальними каналами, а за три квартали 2017 року 5,2 млрд дол., що значно більше, ніж обсяги прямих іноземних інвестицій. Обсяги грошових потоків від трудових мігрантів, ймовірно, були вищими, ніж відображала офіційна статистика, оскільки мігранти здебільшого користувалися неформальними каналами передавання коштів в Україну. За обстеженням Аержстату, 70\% мігрантів привозили гроші особисто або передавали через друзів чи водіїв [24].

Аля владних структур зростання обсягів грошових надходжень від зовнішніх трудових мігрантів мало принаймні два позитивні наслідки. Це дозволяло суттєво зменшити соціальну напруженість у суспільстві в умовах різкого зниження рівня життя населення і одночасно пропагувати позитивні наслідки євроінтеграції для України. Поруч з тим частина коштів була вкладена у будівництво житла, спорудження якого контролювалося олігархічними угрупуваннями, що дозволило покращити їх фінансовий стан.

Як відзначав заступник голови НБУ О. Чурій, трудова міграція була негативним явищем для економіки кураїни у довгостроковій перспективі, але для платіжного балансу зростання обсягів коштів, що надходили від зовнішніх трудових мігрантів, позитивно впливали на валютний ринок [25]. Тобто курс гривні було "врято- 


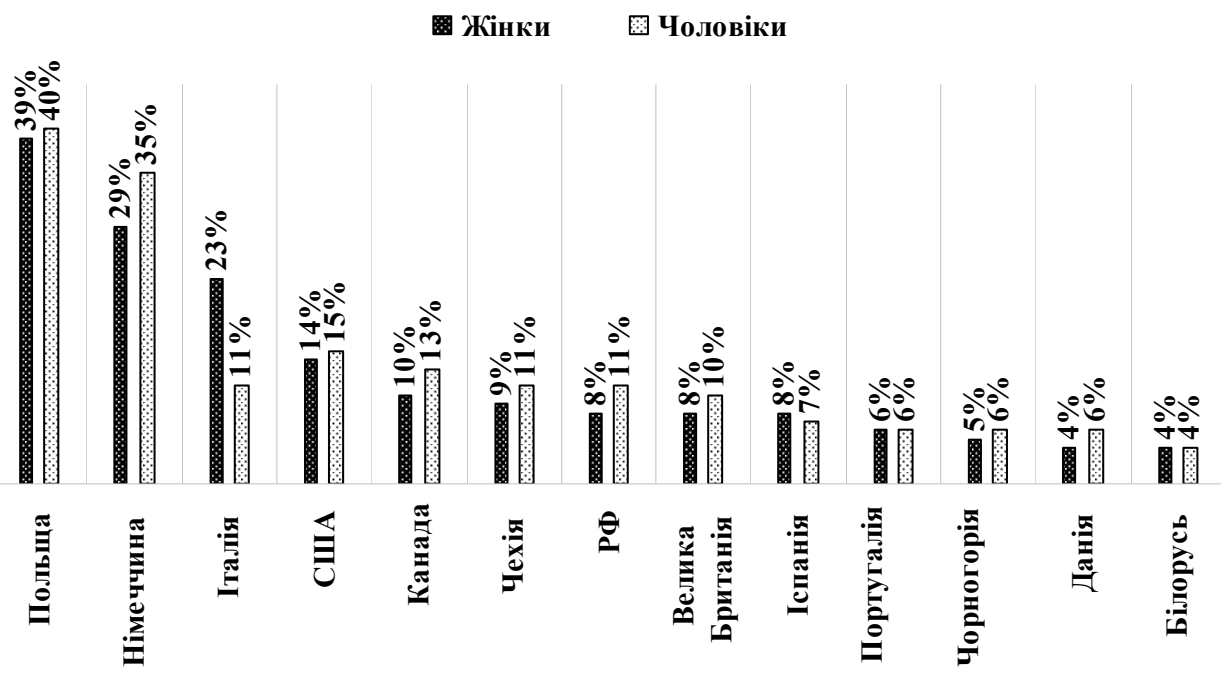

Рис. 2. Найбільш бажані країни для роботи закордоном

Ажерело: [7]

вано" не завдяки зусиллям великих ФПГ, а унаслідок тяжкої праці мільйонів зовнішніх трудових мігрантів, які таким чином прагнули забезпечити добробут своїх сімей у тяжкі роки війни. Вже у 2017 р. обсяги коштів від українських зовнішніх трудових мігрантів сягнули $4 \%$ ВВП [9]. Проте залежність держави від переказів коштів зовнішніх трудових мігрантів свідчить про наявність суттєвих проблем у сфері працевлаштування в Україні та вразливість економіки від коливань на світовому ринку праці. За збереження такого стану речей зростання кількості кваліфікованих працівників за рахунок заохочення зовнішніх трудових мігрантів до повернення на Батьківщину виглядає досить проблематичним. Усвідомлення важливості інвестицій у вигляді переказів коштів зовнішніх трудових мігрантів для розвитку економіки України має стимулювати виважене їх використання. Аля цього мають бути створені умови, за яких такі кошти будуть використані для реального розвитку дрібного бізнесу в Україні.

Проблемою залишилося визначення податкових пільг для мігрантів, які повертаються на батьківщину та вкладають зароблені закордоном кошти у власну справу. Необхідно також вирішити проблему пенсійного страхування працівників-мігрантів. Одним із варіантів такого вирішення може бути укладення угоди щодо соціального забезпечення з країнами їх працевлаштування. Такі угоди мають забезпечувати переказ зароблених коштів за кордону на пенсійне забезпечення в Україні, а також сприяти розвитку системи добровільного пенсійного страхування трудових мігрантів.

Крім того, необхідно підвищувати компетентність мігрантів у фінансових та бізнесових питаннях надаючи їм інформацію та консультації щодо можливостей вигідного інвестування зароблених коштів, працевлаштування та відкриття своєї приватної справи. Необхідно розробити систему податкових пільг для мігрантів, які вкладають зароблені кошти у власний бізнес.

На думку старшого економіста Центру економічної стратегії І. Піонківської, найбільш вагомим позитивним чинником було те, що значну частину зароблених коштів українці привозять в Україну [24]. О.Кваша відзначав, що грошові валютні перекази українських трудових мігрантів збільшували платоспроможність окремих категорій громадян, i, як наслідок, збільшувався сукупний попит на окремі товари і послуги, що слугувало джерелом розвитку відповідних галузей. Грошові перекази стимулювали імпорт через схильність до споживання імпортних товарів і послуг; грошові перекази мали порівняно стабільний характер, на відміну від прямих іноземних інвестицій, що можна було розглядати як надійне джерело надходження іноземної валюти; грошові перекази могли покривати дефіцит торговельного балансу країни; грошові перекази сприяли зниженню рівня бідності та більшому нагромадженню людського капіталу; грошові перекази слугували надійним джерелом покращення соціальних цілей домогосподарств, тобто сприяли збільшенню витрат на охорону здоров'я та освіту [11, с. 539]. Проте, в умовах, коли економіка нашої держави не могла задовольнити попит населення у багатьох товарах, формувався стійкий попит на товари іноземного виробництва. Тому заробітки багатьох зовнішніх трудових мігрантів сприяли розвитку економіки країн, що виробляють товари, виробництво яких не налагоджене в Україні. Таким чином, вигідна для країн $Е С$ порівняно дешева праця українців доповнювалася формуванням ринку збуту для товарів, які вироблялися поза межами України.

Крім того, зовнішня трудова міграція сприяла втраті населення найбільш активного віку із порівняно високим рівнем освіти [33], сприяла зменшенню народжуваності та прискоренню старіння населення.

Зростання масштабів зовнішньої трудової міграції створило суттєві проблеми для розвитку підприємництва в Україні. За даними опитування EY Ernst\&Young People Advisory Services, яка проводить регулярні дослідження ринку праці України з 2002 року, залучаючи понад 250 провідних українських та міжнародних компаній із понад 20 галузей, 2017 року $56 \%$ компаній стикалися зі складнощами у підборі персоналу, в тому числі це пов'язано із зростанням масштабів трудової міграції за кордон. Під кінець 2017 р. суттєво зросла плинність кадрів. 53\% тих, хто звільнився за власним бажанням, як причину вказували саме трудову міграцію за кордон. У 2018 р. 69 \% у опитаних компаній вважають, що проблема трудової міграції буде серйозно впливати на їх діяльність у наступні 3 роки, $43 \%$ компаній мали труднощі 3 залученням та утриманням співробітників в Україні через трудову міграцію, $28 \%$ компаній передбачали ризики через трудову міграцію у майбутньому [8].

\section{ВИСНОВКИ}

Ситуативне використання коштів зовнішніх трудових мігрантів для покращення платіжного балансу, стабілізації української валюти, послаблення соціальної напруженості у суспільстві вже обертається проблемами, які у найближчому майбутньому можуть створити цілий комплекс загроз національній безпеці. 
Ао негативних наслідків зростання масштабів зовнішньої трудової міграції можна також віднести скорочення інноваційного потенціалу України через втрату найбільш кваліфікованих працівників і, відповідно, неможливість реалізувати інноваційні проекти. Україна поглиблює відставання від провідних країн світу за рівнем інвестування, оскільки інформація про причини зовнішньої трудової міграції поширюється стараннями самих мігрантів. Значна кількість підприємств України відчуває не лише брак кваліфікованих працівників, а й працівників, здатних виконувати роботу нижчої кваліфікації. На переконання багатьох молодих працівників на теренах України не може бути забезпечена їх самореалізація. Поширення такого переконання негативно впливає не лише на виробництво, а й на освітянську діяльність. Оскільки прагнення молоді отримувати освіту за кордоном для того, щоб мати конкуренті переваги на зовнішніх ринках праці, негативно позначилося на наборах абітурієнтів в українських вузах. При тому частина студентів вже планує після отримання ступеня бакалавра в Україні продовжити навчання за кордоном Аля отримання ступеня магістра.

Важливо, що зростання масштабів зовнішньої трудової міграції і масштабне залучення молоді до цього процесу негативно впливає на обороноздатність держави. Адже частина військовозобов'язаних перебуває поза межами України, а інноваційний потенціал багатьох інших використовується на благо інших держав.

Мітература:

1. Бабенко М. Країна без працівників. Чому українці масово виїжджають за кордон. URL: https:// news.finance.ua/ua/news/-/ 423173/krayina-bez-pratsivnykivchomu-ukraintsi-masovo-vyyizhdzhayut-pratsyuvaty-zakordon

2. Буров I. Трудова міграція як наслідок соціальноекономічної політики України 2014-2018 рр.// Українське суспільство: моніторинг соціальних змін. зб. наук. праць. Вип. 6 (20). Київ: Інститут соціології НАН УКраїни, 2018. С. $166-170$.

3. В Украине наблюдается редкий для Европы феномен - нищета работающих // Кореспондент. URL: http:// korrespondent.net/business/career/1478140korrespondent-v-ukraine-nablyudaetsya-redkij-dlyaevropy-fenomen-nishcheta-rabotayushchih

4. Василик О.А., Василик А.О. Бюджетні методи регулювання економічного і соціального розвитку // Вісник Київськ. Нац. ун-ту. Серія: економіка. 2004. № 70 . C. $4-8$.

5. Все меньше украинцев согласны ехать на заработки в Россию. UPL: https://www.rupor.info/news/122365/ vse-menshe-ukraintsev-soglasny-ehat-na-zarabotki-vrossiyu

6. Гайдуцький А. 2018 Що робити Україні в епоху високого попиту на українців? URL: https://dt.ua/ internal/borotba-za-migrantiv-ukrayini-prigotuvatisya289703 .html

7. Аослідження з питань міграції та торгівлі людьми в Україні, 2017 / GfK Ukraine на замовлення Представництва Міжна родної організації з міграції (MOM) в Україні. URL: http://iom.org.ua/sites/default/files/ migration_and_human_trafficking_in_ukraine_2017_ukr.pdf

8. Зайуда А. Робсила чи рабсила: як впливає на економіку України трудова мігращія. URL: https:/ www.bbc.com/ukrainian/features-43485101

9. Заробитчане перевели из Польши в Украину почти 4\% ВВП. URL: http://hvylya.net/news/digest/ zarobitchane-pereveli-iz-polshi-v-ukrainu-pochti-4vvp.html

10. Звонар В. Теорія і практика ефективного регулювання мінімальної заробітної плати в Україні// Україна: аспекти праці. Науково-економічний та суспільно-політичний журнал. 2010. № 3. С. $21-26$.
11. Кваша О.С. Зовнішні міграційні процеси трудових ресурсів: фактори, стан та наслідки для Украіни // Економіка і суспільство. 2017. № 10. С. 535-540.

12. Клівіденко А.М. Фінансове забезпечення соціального захисту населення України. Автореф. дис... канд. екон. наук. Тернопіль, 2006. 24 с.

13. Корнієнко О.О. Особливості сучасного етапу міжнародних міграційних процесів. Економічний простір: Збірник наукових праць. № 104. Аніпропетровськ: ПААБА, 2015. С. 28-43.

14. Мібанова Е.M. Зовнішня трудова міграція українців: масштаби, причини, наслідки // Аемографія та соціальна економіка. 2018. № 2 (33). С. 11-26.

15. Малиновська О.А. Мігранти, міграція та Українська держава: аналіз управління зовнішніми міграціями: монографія. Київ: ВиА-во НААУ, 2004. 236 с.

16. Малиновська О.А. Міграційна криза в Європі: пошуки шляхів розв'язання та наслідки для України Стратегічні пріоритети. 2016. № 3 (40). С. 104-114.

17. Малиновська О.А. Міграційна політика: глобальний контекст та українські реалії: монографія / О.А. Малиновська. Київ: НICА, 2018. 472 с.

18. Малиновська О.А. Перекази мігрантів 3-за кордону: обсяги, канали, соціально-економічне значення: аналіт. доп. Київ: НICA, 2014. 60 с.

19. Мандибура В.О. Рівень життя населення та механізми його регулювання. Автореф. дис. докт. екон. наук. Київ, 1999. 19 с.

20. Наслідки міграційних процесів: нові виклики та можливості для регіонів / НАН України, АУ "Інститут регіональних досліджень імені М.І.Аолішнього"; наук. ред. У.Я.Садова. Аьвів, 2015.252 с.

21. Осовий Г. Питання реформи оплати праці в $\mathrm{V}_{\mathrm{K}-}$ раїні в контексті реалізації Плану дій щодо євроінтеграції // Україна: аспекти праці. 2005. № 3. С. 3-11.

22. Перерахунок даних щодо приватних грошових переказів в Україну за 2015-2017 роки / Національний банк України. URL: https://bank.gov.ua/doccatalog/ document?id $=66364144$

23. Петрушина Т., Соколовський І. Соціологічні показники стану ринку праці України: актуальні проблеми та виклики // Українське суспільство: моніторинг соціальних змін. зб. наук. праць. Вип. 6 (20). Київ: Інститут соціологї̈ НАН України, 2018. С. 139-147.

24. Піонтківська I. Трудова міграція українців: позитив теж є. URL: https://www.epravda.com.ua/columns/ 2018/02/28/634533/

25. Поступления от заробитчан в этом году превысят \$11 миллиардов. - НБУ. URL: https://biz.censor.net.ua/news/3083250/postupleniya ot zarobitchan v_etom_godu_prevysyat_11_milliardov_n̄

26. Прибиткова I. Пересувні ринки праці за доби незалежності України та міграційні плани українців. Українське суспільство: моніторинг соціальних змін. Київ, 2015. С. 316-327.

27. Рахманов О.А. Власники великого капіталу як соціальна основа української державності // Українське суспільство на шляху до політичної нації: історія і сучасність. Київ: КНЕУ, 2014. С. 378-396.

28. Снігова О. Ю. Механізм державного та регіонального управління соціальною безпекою. Автореф. дис... канд. екон. наук. Аонецьк, 2006. 22 с.

29. Соціально-економічна захищеність мігрантів: глобальні та регіональні аспекти / $А$ У "Інститут регіональних досліджень імені М.I. Аолішнього НАН України"; наук. ред. У.Я. Садова. Аьвів, 2016. 266 с.

30. Українське суспільство: міграційний вимір: нац. доповідь / Інститут демографії та соціальних досліджень ім. М.В. Птухи НАН України. Київ, 2018. 396 с.

31. Шевченко $\Lambda$. Мінімальна заробітна плата та їі рівень: теоретичне осмислення проблеми. Україна: аспекти праці. 2003. № 4. С. 30-33.

32. Jozwiak I., Piechowska M. Crisis-driven Mobility between Ukraine and Poland. URL: http://www.mig- 
racje.uw.edu.pl/wp-content/uploads/2017/05/WP99157.pdf

33. External Labour Migration In Ukraine As A Factor In Socio-Demographic And Economic Development. URL: http://www.carim-east.eu/media/CARIM-East-2012-RR14.pdf

\section{References:}

1. Babenko, M. (2018), "A country without workers. Why Ukrainians go abroad massively", available at: https:/ /news.finance.ua/ua/news/ -/423173/krayina-bezpratsivnykiv-chomu-ukraintsi-masovo-vyyizhdzhayutpratsyuvaty-za-kordon (Accessed 30 Sept 2019).

2. Burov, I. (2018), "Labor migration as a consequence of the socio-economic policy of Ukraine 2014-2018", Ukrainske suspilstvo: monitorynh sotsialnykh zmin. zb. nauk. prats, vol. 6 (20), pp.166-170.

3. korrespondent.net (2013), "In Ukraine can be observed a rare phenomenon in Europe - the poverty of workers", Available at: http://korrespondent.net/business/ career/1478140-korrespondent-v-ukraine-nablyudaetsyaredkij-dlya-evropy-fenomen-nishcheta-rabotayushchih (Accessed 30 Sept 2019).

4. Vasylyk, O. D. and Vasylyk, D. O. (2004), "Budgetary methods of regulation of economic and social development", Visnyk Kyivsk. Nats. un-tu. Seriia: ekonomika, vol. 70, pp. $4-8$.

5. rupor.info (2017), "Fewer Ukrainians agree to go to work in Russia", Available at: https://www.rupor.info/ news/122365/vse-menshe-ukraintsev-soglasny-ehat-nazarabotki-v-rossiyu (Accessed 30 Sept 2019).

6. Haidutskyi, A. (2018), "What should Ukraine do in an era of high demand for Ukrainians?", Available at: https:/ /dt.ua/internal/borotba-za-migrantiv-ukrayiniprigotuvatisya-289703_.html (Accessed 30 Sept 2019).

7. GfK Ukraine commissioned by the International Organization for Migration (IOM) Office in Ukraine (2017), "Research on migration and human trafficking in Ukraine", Available at: http://iom.org.ua/sites/default/files/ migration and human trafficking in_ukraine_2017_ukr.pdf (Accessed 30 Sept 2019).

8. Zanuda, A. (2018), "Robsil or Slavery", Available at: https://www.bbc.com/ukrainian/features-43485101 (Accessed 30 Sept 2019).

9. hvylya.net (2018), "The workers were transferred from Poland", Available at: http://hvylya.net/news/digest/ zarobitchane-pereveli-iz-polshi-v-ukrainu-pochti-4vvp.html (Accessed 30 Sept 2019).

10. Kvasha, O. S. (2017), "External migration processes of labor resources: factors, status and consequences for Ukraine", Available at: http://economyandsociety.in.ua/ journal/10_ukr/92.pdf (Accessed 30 Sept 2019).

11. Kvasha, O. S. (2017), "External migration processes of labor resources: factors, status and consequences for Ukraine", Ekonomika i suspilstvo, vol. 10, pp. 535-540.

12. Klividenko, L. M. (2006), "Financial support for social protection of the population of Ukraine", Ph.D. Thesis, Economy, Ternopil, Ukraine.

13. Korniienko, O. O. (2015), "Features of the current stage of international migration processes", Ekonomichnyi prostir: Zbirnyk naukovykh prats, vol. 104, pp. 28-43.

14. Libanova, E. M. (2018), "External labor migration of Ukrainians: scale, causes, consequences", Demohrafiia ta sotsialna ekonomika. № 2 (33), pp. 11-26.

15. Malynovska, O. A. (2004), Mihranty, mihratsiia ta Ukrainska derzhava: analiz upravlinnia zovnishnimy mihratsiiamy [Migrants, Migration and the Ukrainian State: An Analysis of External Migration Management], Vyd-vo NADU, Kyiv, Ukraine.

16. Malynovska, O.A. (2016), "The Migration Crisis in Europe: Finding Ways and Implications for Ukraine", Stratehichni priorytety, vol. 3 (40), pp. 104-114.

17. Malynovska, O.A. (2018), Mihratsiina polityka: hlobalnyi kontekst ta ukrainski realii [Migration Policy: A
Global Context and Ukrainian Realities], NISD, Kyiv, Ukraine.

18. Malynovska, O. A. (2014). Perekazy mihrantiv z-za kordonu: obsiahy, kanaly, sotsialno-ekonomichne znachennia [Migrant transfers from abroad: volumes, channels, socio-economic value], Vyd-vo NADU, Kyiv, Ukraine.

19. Mandybura, V. O. (1999), "The standard of living of the population and the mechanisms of its regulation", Ph.D. Thesis, Economy, Kyiv, Ukraine.

20. Sadov, U.Ia. (2015). Naslidky mihratsiinykh protsesiv [Consequences of migration processes], NAN Ukrainy, DU "Instytut rehionalnykh doslidzhen imeni M.I.Dolishnoho", Lviv, Ukraine.

21. Osovyi, H. (2005), "Issues of pay reform in Ukraine in the context of the implementation of the European Integration Action Plan", Ukraina: aspekty pratsi, vol. 3, pp. 3-11.

22. National Bank of Ukraine (2018), "Conversion of private data", Available at: https://bank.gov.ua/ doccatalog/document?id=66364144 (Accessed 30 Sept 2019).

23. Petrushyna, T. and Sokolovskyi, I. (2018), "Sociological indicators of the state of the Ukrainian labor market: current problems and challenges",Ukrainske suspilstvo: monitorynh sotsialnykh zmin. zb. nauk. prats, vol. 6 (20), pp. $139-147$.

24. Piontkivska, I. (2018), "Labor migration of Ukrainians: there are positives too", Available at: https:// www.epravda.com.ua/ columns/2018/02/28/634533/ (Accessed 30 Sept 2019).

25. biz.censor (2018), "Proceeds from earnings this year will exceed \$ 11 billion, - NBU", Available at: https:// biz.censor.net.ua/news/3083250/ postupleniya_ot_zarobitchan_v_etom_godu_prevysyat_11_milliardov_nbu (Accessed 30 Sept 2019).

26. Prybytkova, I. (2015), "Mobile labor markets for the independence of Ukraine and migration plans of Ukrainians", Ukrainske suspilstvo: monitorynh sotsialnykh zmin. Kyiv, pp. 316-327.

27. Rakhmanov, O. A. (2014), "Owners of big capital as the social basis of Ukrainian statehood", Ukrainske suspilstvo na shliakhu do politychnoi natsii: istoriia i suchasnist [Ukrainian society on the path to a political nation: history and modernity], KNEU, Kyiv, Ukraine, pp. $378-396$.

28. Snihova, O. Yu. (2006), "The mechanism of state and regional management of social security", Ph.D. Thesis, Economy, Donetsk, Ukraine.

29. (2016), Sotsialno-ekonomichna zakhyshchenist mihrantiv: hlobalni ta rehionalni aspekty [Socio-economic protection of migrants: global and regional aspects]. DU "Instytut rehionalnykh doslidzhen imeni M. I. Dolishnoho NAN Ukrainy", Lviv, Ukraine.

30. Instytut demohrafii ta sotsialnykh doslidzhen im. M.V. Ptukhy (2018), Ukrainske suspilstvo: mihratsiinyi vymir [Ukrainian Society: The Migration Dimension], Instytut demohrafii ta sotsialnykh doslidzhen im. M.V.Ptukhy NAN Ukrainy, Kyiv, Ukraine.

31. Shevchenko, L. (2003), "Minimum wage and its level: theoretical understanding of the problem", Ukraina: aspekty pratsi, vol. 4, pp. 30-33.

32. Jozwiak, I. and Piechowska, M. (2017), "Crisis-driven Mobility between Ukraine and Poland", CMR Workiing Papers, Available at: http://www.migracje.uw.edu.pl/wpcontent/uploads/2017/05/WP99157.pdf (Accessed 30 Sept 2019).

33. Pozniak, O. (2012), "External Labour Migration In Ukraine As A Factor In Socio-Demographic And Economic Development", CARIM East - Consortium for Applied Research on International Migration, Available at: http:// www.carim-east.eu/media/CARIM-East-2012-RR-14.pdf (Accessed 30 Sept 2019).

Стаття надійила до редакиіï 07.10.2019 p. 